\title{
The respiratory health effects of nitrogen dioxide in children with asthma
}

\author{
J. Gillespie-Bennett*, N. Pierse*, K. Wickens" ${ }^{\#}$ J. Crane ${ }^{\#}$, \\ P. Howden-Chapman*, and the Housing Heating and Health Study Research Team*
}

ABSTRACT: There is growing evidence that asthma symptoms can be aggravated or events triggered by exposure to indoor nitrogen dioxide $\left(\mathrm{NO}_{2}\right)$ emitted from unflued gas heating.

The impact of $\mathrm{NO}_{2}$ on the respiratory health of children with asthma was explored as a secondary analysis of a randomised community trial, involving 409 households during the winter period in 2006 (June to September).

Geometric mean indoor $\mathrm{NO}_{2}$ levels were $11.4 \mu \mathrm{g} \cdot \mathrm{m}^{-3}$, while outdoor $\mathrm{NO}_{2}$ levels were $7.4 \mu \mathrm{g} \cdot \mathrm{m}^{-3}$. Higher indoor $\mathrm{NO}_{2}$ levels (per logged unit increase) were associated with greater daily reports of lower (mean ratio 14, 95\% $\mathrm{Cl} 1.12-1.16)$ and upper respiratory tract symptoms (mean ratio 1.03, 95\% $\mathrm{Cl}$ 1.00-1.05), more frequent cough and wheeze, and more frequent reliever use during the day, but had no effect on preventer use. Higher indoor $\mathrm{NO}_{2}$ levels (per logged unit increase) were associated with a decrease in morning $(-17.25 \mathrm{~mL}, 95 \% \mathrm{Cl}-27.63--6.68)$ and evening $(-13.21,95 \%$ $\mathrm{Cl}-26.03--0.38$ ) forced expiratory volume in $1 \mathrm{~s}$ readings. Outdoor $\mathrm{NO}_{2}$ was not associated with respiratory tract symptoms, asthma symptoms, medication use or lung function measurements.

These findings indicate that reducing $\mathrm{NO}_{2}$ exposure indoors is important in improving the respiratory health of children with asthma.

KEYWORDS: Asthma, children, heating, nitrogen dioxide, randomised community trial

A sthma is one of the most prevalent chronic diseases in childhood. It imposes a heavy burden on healthcare expenditure and reduces quality of life for individuals and their families. There is growing evidence that asthma symptoms can be aggravated or even triggered by exposure to indoor nitrogen dioxide $\left(\mathrm{NO}_{2}\right)$ emitted from unflued gas heating and cooking appliances [1-4].

While human controlled-exposure studies have reported associations between $\mathrm{NO}_{2}$ and respiratory symptoms such as wheeze and cough [5-7], epidemiological evidence for the association between $\mathrm{NO}_{2}$ exposure and respiratory symptoms has been inconsistent. This inconsistency is partly due to methodological problems, confounding or effect modification by other pollutants, and a lack of prospective data $[8,9]$. To some extent, this inconsistency in epidemiological studies also relates to the differences between the groups of people who have been studied. Populations have included healthy children $[4,10,11]$, children with asthma [1, 12, 13], infants [14, 15] and adults with and without asthma [16-19].

Despite methodological differences, a systematic review, involving 23 outdoor and 36 indoor studies, assessed the role of $\mathrm{NO}_{2}$ in respiratory diseases. The review concluded that respiratory effects were associated with levels of $\mathrm{NO}_{2}$ encountered in common domestic and outdoor settings [20]. Another systematic review of the health effects caused by environmental $\mathrm{NO}_{2}$ reported that there was moderate evidence that short-term exposure $(24 \mathrm{~h})$, even for mean values $<50 \mu \mathrm{g} \cdot \mathrm{m}^{-3} \mathrm{NO}_{2}$, increased both hospital admissions and mortality [21]. The review also reported that there was moderate evidence that long-term exposure to an $\mathrm{NO}_{2}$ level below the World Health Organization (WHO) recommended air quality annual mean guideline of $40 \mu \mathrm{g} \cdot \mathrm{m}^{-3}$ was associated with adverse health effects (respiratory symptoms/diseases, hospital admissions, mortality and otitis media).

Few community randomised controlled trials have been conducted on the effects of $\mathrm{NO}_{2}$ on respiratory health. In 2004, PiLOtTo et al. [2] reported the first randomised controlled trial. Their study intervention involved removing high exposures to $\mathrm{NO}_{2}$ by replacing unflued gas heaters in schools with flued gas or electric heaters. The study reported a reduction in the rates of difficult breathing, chest tightness and daytime asthma attacks.

We report a secondary analysis of a clustered, randomised control trial (identifier NCT00489762)

\section{AFFILIATIONS}

*Housing and Health Group, Dept of Public Health, Wellington School of Medicine and Health Sciences,

University of Otago, and

"Wellington Asthma Research

Group, Dept of Medicine, University of Otago, Wellington, New Zealand.

CORRESPONDENCE

J. Gillespie-Bennett He Kainga Oranga-Housing and Health Research Programme Dept of Public Health University of Otago Wellington

PO Box 7343 Wellington New Zealand E-mail: Julie.Bennett@otago.ac.nz

Received:

July 212009

Accepted after revision: Nov 102010 First published online: Dec 222010 
designed to assess the effects of a heating intervention. The Housing, Heating and Health Study [22] has previously shown that homes in this study with unflued gas heating had significantly higher levels of $\mathrm{NO}_{2}$ in their living rooms than homes that did not use this form of heating [23]. The primary aim of our study was to investigate the impact of $\mathrm{NO}_{2}$ on the respiratory health of children with asthma in the home environment. A secondary aim was to investigate the effect of outdoor $\mathrm{NO}_{2}$ on these children.

\section{METHODS}

\section{Study design}

The Housing, Heating and Health Study [22] was carried out between June and September 2006 in five communities in New Zealand (Bluff, Dunedin, Christchurch, Porirua and the Hutt Valley). This study presents a secondary analysis of the impact of $\mathrm{NO}_{2}$ on the health of children with asthma.

\section{Study population}

A flow chart of the recruitment and retention progress throughout the study is shown in figure 1.

\section{$\mathrm{NO}_{2}$ measurements}

We piloted the use of passive diffusion tubes to measure $\mathrm{NO}_{2}$ in 203 homes during the winter period in 2005 (June until September) [24]. Passive diffusion tubes consist of an acrylic tube with a mesh steel cap that is coated in an absorbent (triethanolamine) at one end and a removable cap at the other end which, once opened, starts the sampling period. These tubes were inserted into spacers that held the tubes $5 \mathrm{~cm}$ away from the wall at a height of $1.8 \mathrm{~m}$ from the ground. Over the
2006 winter, $\mathrm{NO}_{2}$ was measured over four 4-week sampling periods in 349 living rooms. Outdoor $\mathrm{NO}_{2}$ (from the back porches of the homes) was measured over the final 4-week sampling period.

After 4 weeks, the tubes were collected, sealed, and returned to the study centre. $\mathrm{NO}_{2}$ concentrations were determined in a single laboratory colorimetrically as nitrite using Griess-Saltzman reagent [24]. The azo dye-forming reagent was prepared as described previously [24] and contained $N$-(1-naphthyl) ethylenediamine dihydrochloride, de-ionised water, orthophosphoric acid $\left(\mathrm{H}_{3} \mathrm{PO}_{4}\right)$, and sulfanilic acid. The reagent was fresh for each analytical run.

\section{Outcome measures}

Our primary outcomes were measures of lung function: peak expiratory flow rate (PEFR) and forced expiratory volume in 1 s (FEV1). Small hand-held spirometers, "Piko-meters", were given to each child and their correct use explained by community co-ordinators. During the winter of 2005 the Piko-meter's internal recording device was used to select the best of three blows every morning and evening from 297 children. However, due to the high number of implausible readings recorded during the winter of $2005(>5 \%)$, in 2006 more emphasis was placed on teaching the children the correct technique, as well as asking them to record up to five blows (morning and evening) in a symptom diary. Symptom diaries were designed to record symptoms for the entire study period (112 days per child). Daily measures of asthma severity and upper respiratory tract symptoms were recorded in the symptom diaries by 360 children in 2006. Each respiratory

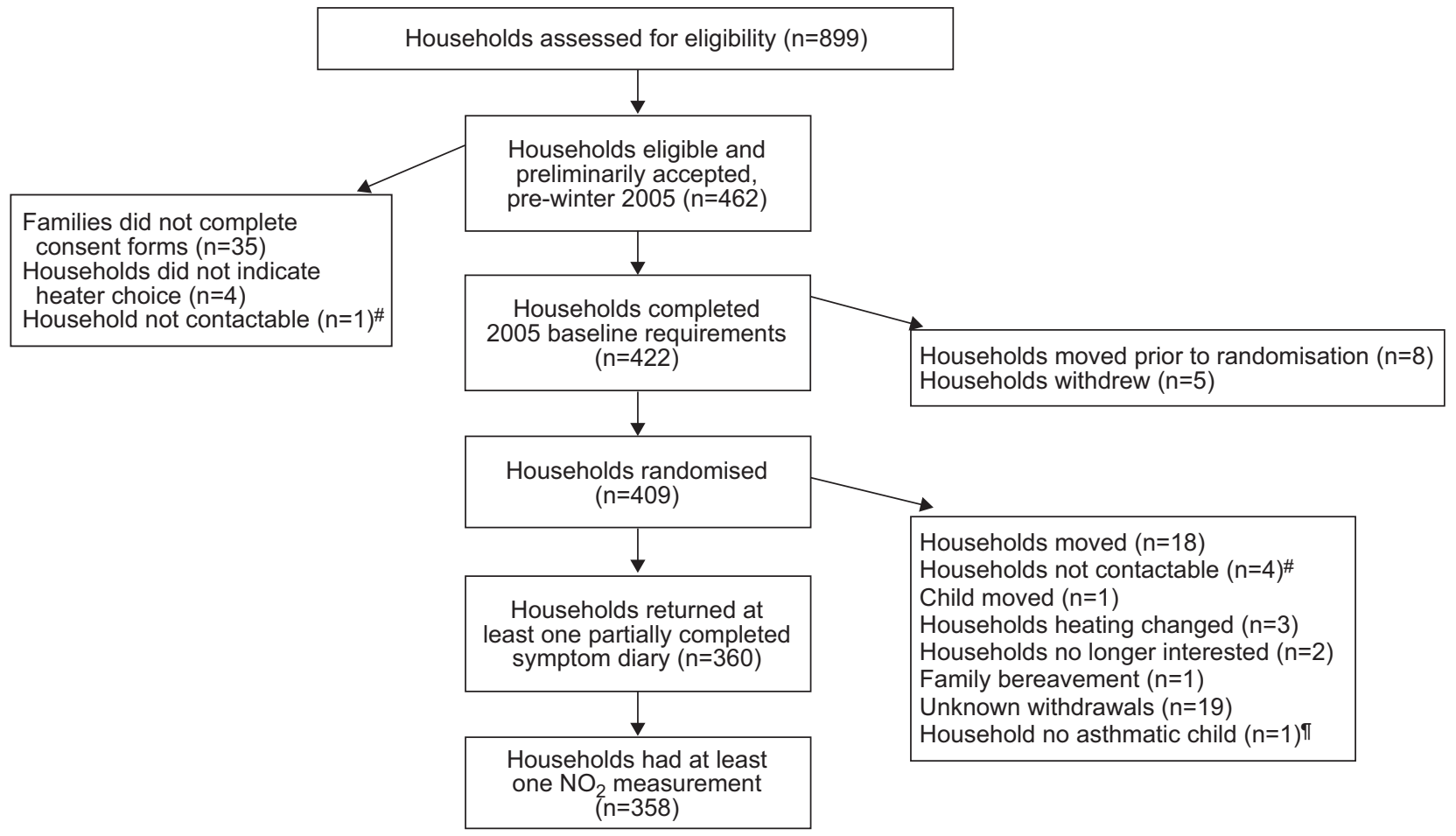

FIGURE 1. Flow chart of the recruitment and retention progress throughout the study. ${ }^{\#}$ : unable to make contact after at least three phone calls, two letters and community-coordinator visits, it is probable that these households have moved but we are unable to confirm this; " : did not meet entry criteria (child with asthma) and were dropped when this finally became clear after cross checking with the community coordinator. 
symptom was recorded on a nominal severity scale from 0 to 3 as used by CHAUHAN et al. [12], with " 0 " representing the absence of a symptom and " 3 " representing the greatest severity level. Symptoms of cough at night, cough on waking, wheeze at night and wheeze on waking were recorded each morning. Cough and wheeze during the day and number of preventer and reliever puffs were recorded in the evening. Lower respiratory symptoms were defined as cough on waking, wheeze on waking, night-time cough and wheeze during the night, while upper respiratory tract symptoms were defined as having a runny nose or sneezing, blocked or stuffy nose, sore throat or hoarse voice, headaches or face aches, and aches and pains elsewhere. The median return for recorded symptoms was 81 days and lung function measures were recorded over a median of 72 days.

\section{Ethical approval}

Multi-region ethics approval was obtained before recruitment commenced. Parents signed consent forms on behalf of their children.

\section{Statistical analysis}

Data were cleaned and analysed using $\mathrm{R}$ version 2.9.1 (www.rproject.org). $\mathrm{NO}_{2}$ measurements were log normally distributed, so the analysis was based on log-transformed $\mathrm{NO}_{2}$ measures. The maximum morning and evening FEV1 and PEFR were used in the analysis. Reported daily health symptoms and spirometry were matched to the $\mathrm{NO}_{2}$ level measured in the corresponding month. For example, an FEV1 or PEFR reading taken on day 10 was matched to the $\mathrm{NO}_{2}$ level measured during the first 4-week period of the study.

During 2006 (study year), outcomes and $\mathrm{NO}_{2}$ measurements were used in the models, the 2005 (pilot year) outcomes were not included in order to reduce model complexity. Linear mixed-effects models were used to analyse the data. These models consisted of two levels. The first level consisted of the random effects of the repeated measures on the same individuals. The second level captured the fixed linear effects of $\mathrm{NO}_{2}$ on health outcomes. Outcomes for the linear mixed-effects models were daily maximum FEV1 and PEFR, and daily symptom scores.

\begin{tabular}{|c|c|c|}
\hline TABLE 1 & \multicolumn{2}{|c|}{$\begin{array}{l}\text { Participants characteristics, nitrogen dioxide } \\
\left(\mathrm{NO}_{2}\right) \text { levels and temperature during the winter of } \\
2006\end{array}$} \\
\hline Subjects $n$ & & 349 \\
\hline Males & & 58.6 \\
\hline \multicolumn{2}{|c|}{ Mean age at baseline yrs } & 9.6 \\
\hline \multicolumn{2}{|c|}{ Mäori children } & 35.0 \\
\hline \multicolumn{2}{|c|}{ New Zealand-European children } & 63.0 \\
\hline \multicolumn{2}{|c|}{ Pacific children } & 16.9 \\
\hline \multicolumn{2}{|c|}{ Other ethnicity } & 13.5 \\
\hline \multicolumn{2}{|c|}{ Indoor $\mathrm{NO}_{2}$ level $\mu \mathrm{g} \cdot \mathrm{m}^{-3}$} & 11.4 \\
\hline \multicolumn{2}{|c|}{ Outdoor $\mathrm{NO}_{2}$ level $\mu \mathrm{g} \cdot \mathrm{m}^{-3}$} & 7.4 \\
\hline \multicolumn{2}{|c|}{ Mean indoor temperature ${ }^{\circ} \mathrm{C}$} & 16.5 \\
\hline
\end{tabular}

The results are presented as the mean change in lung function per logged unit of $\mathrm{NO}_{2}$ or the change in mean symptom rate per unit increase in logged $\mathrm{NO}_{2}$. A one-unit change in $\mathrm{NO}_{2}$ is approximately the same as moving from the 25th percentile to the 75th percentile. Indoor $\mathrm{NO}_{2}$ was measured for up to 16 weeks (112 days) per child and outdoor $\mathrm{NO}_{2}$ was measured for one 4-week period in September 2006. A sensitivity analysis was performed to assess the presence of a threshold effect of $\mathrm{NO}_{2}$ exposure, but no threshold effect was found. Because of differences in the period of measurement between indoor and outdoor $\mathrm{NO}_{2}$, the models with indoor $\mathrm{NO}_{2}$ cover the entire winter period and have four times as many data points as models that include outdoor $\mathrm{NO}_{2}$, which only cover the final 4 weeks of the winter period.

\section{RESULTS}

At baseline $58.6 \%$ of children were male and the average age was 9.6 yrs (range 6-13 yrs) (table 1). The study had a higher proportion of Mäori and Pacific children than the national average of children aged $5-14$ yrs (22.5\% and $11.1 \%$, respectively), but the percentage of New Zealand-European participants was similar to the national average of $61.7 \%$. The indoor $\mathrm{NO}_{2}$ geometric mean was $11.4 \mu \mathrm{g} \cdot \mathrm{m}^{-3}$ while the outdoor $\mathrm{NO}_{2}$ geometric mean was $7.4 \mu \mathrm{g} \cdot \mathrm{m}^{-3}$.

The mean of the cough symptom scores ranged between 0.44 and 0.59 on a scale of 0 to 3 (table 2). Similarly for wheeze, the average scores ranged between 0.27 and 0.37. Among all children the mean FEV1 morning and evening readings were 2,065 $\mathrm{mL}$ and 2,507 $\mathrm{mL}$, respectively, and the mean PEFR morning and evening readings were $282.7 \mathrm{~L} \cdot \mathrm{min}^{-1}$ and $283.0 \mathrm{~L} \cdot \mathrm{min}^{-1}$, respectively.

The effects per logged unit increase in $\mathrm{NO}_{2}$ on daily symptom scores are reported as mean ratios in table 3 . This table shows a consistent and significant increase in lower (change in mean symptom rate per unit increase in $\mathrm{NO}_{2} 1.14,95 \%$ CI 1.12-1.16)

\begin{tabular}{|c|c|c|c|}
\hline $\begin{array}{l}\text { Mean daily } r \\
\text { medication } \\
\text { during the w }\end{array}$ & $\begin{array}{l}\text { spiratory syn } \\
\text { e and lung fu } \\
\text { iter of } 2006\end{array}$ & $\begin{array}{l}\text { tom score } \\
\text { iction meas }\end{array}$ & ements \\
\hline Health event & Child days $n$ & Subjects $n$ & Mean \\
\hline Cough at night & 26546 & 344 & 0.45 \\
\hline Cough during the day & 27364 & 358 & 0.59 \\
\hline Cough on waking & 26528 & 344 & 0.44 \\
\hline Wheeze at night & 26421 & 343 & 0.29 \\
\hline Wheeze during the day & 27133 & 356 & 0.37 \\
\hline Wheeze on waking & 26431 & 343 & 0.27 \\
\hline Preventer use & 27583 & 356 & 1.56 \\
\hline Reliever puffs per day & 27277 & 357 & 1.08 \\
\hline Lower respiratory symptoms & 23475 & 337 & 2.40 \\
\hline Upper respiratory symptoms & 26860 & 353 & 1.57 \\
\hline Evening FEV $1 \mathrm{~mL}$ & 23428 & 357 & 2507 \\
\hline Morning FEV1 mL & 22163 & 347 & 2065 \\
\hline Evening PEFR L. $\min ^{-1}$ & 23435 & 357 & 282.7 \\
\hline Morning PEFR L· $\min ^{-1}$ & 22456 & 348 & 283.0 \\
\hline
\end{tabular}

FEV1: forced expiratory volume in $1 \mathrm{~s}$; PEFR: peak expiratory flow rate. 


\begin{tabular}{|c|c|c|c|c|}
\hline Health event & Child days $n$ & Subjects $\mathbf{n}$ & $\begin{array}{l}\text { Change in mean symptom rate } \\
\text { per unit increase in } \mathrm{NO}_{2}\end{array}$ & $95 \% \mathrm{Cl}$ \\
\hline Cough at night & 25528 & 344 & 1.16 & $1.12-1.21$ \\
\hline Cough during the day & 26329 & 358 & 1.12 & $1.08-1.16$ \\
\hline Wheeze at night & 25406 & 343 & 1.12 & $1.06-1.19$ \\
\hline Wheeze during the day & 26101 & 356 & 1.06 & $1.01-1.12$ \\
\hline Wheeze on waking & 25417 & 343 & 1.12 & $1.06-1.18$ \\
\hline Preventer use & 26522 & 356 & 0.99 & $0.98-1.01$ \\
\hline Reliever puffs per day & 26234 & 357 & 1.14 & $1.11-1.17$ \\
\hline Lower respiratory symptoms & 22756 & 337 & 1.14 & $1.12-1.16$ \\
\hline
\end{tabular}

and upper (change in mean symptom rate per unit increase in $\left.\mathrm{NO}_{2} 1.03,95 \% \mathrm{CI} 1.00-1.05\right)$ respiratory tract symptoms with exposure to increased $\mathrm{NO}_{2}$. The change in mean symptom rate per unit increase in $\mathrm{NO}_{2}$ was also significant for the positive associations between indoor $\mathrm{NO}_{2}$ and all cough and wheeze symptoms. An increase in indoor $\mathrm{NO}_{2}$ exposure was also significantly related to reliever use during the day. Indoor $\mathrm{NO}_{2}$ had no effect on preventer use.

A log scale was used as $\mathrm{NO}_{2}$ is log normally distributed. To help interpret the tables a one unit change in both outdoor and indoor $\mathrm{NO}_{2}$ is approximately the same as moving from the 25th percentile to the 75 th percentile i.e. if someone was to move from a "low" $\mathrm{NO}_{2}\left(5.5 \mu \mathrm{g} \cdot \mathrm{m}^{-3}\right)$ house or area to a "high" $\mathrm{NO}_{2}\left(15.9 \mu \mathrm{g} \cdot \mathrm{m}^{-3}\right)$ house or area this would, on average, result in increasing their cough at night symptoms by 1.16 times.

The results for the association between indoor $\mathrm{NO}_{2}$ and lung function are reported in table 4 . These show a consistent decrease in lung function with increasing indoor $\mathrm{NO}_{2}$, which is significant for morning and evening FEV1 readings.

Outdoor $\mathrm{NO}_{2}$ was measured only during the last 4-weeks of the winter period. Table 5 shows that in this restricted sample mean outdoor $\mathrm{NO}_{2}$ was not significantly associated with any of the asthma symptoms or medication use.

The results for the association between outdoor $\mathrm{NO}_{2}$ and lung function are reported in table 6. A unit change in outdoor $\mathrm{NO}_{2}$ was associated with a greater change in lung function than a unit change in indoor $\mathrm{NO}_{2}$, although none of the outdoor $\mathrm{NO}_{2}$ associations were significant.

While table 4 shows the effect of indoor $\mathrm{NO}_{2}$ on lung function, it was also of interest how much of this relationship was due to outdoor $\mathrm{NO}_{2}$. As outdoor $\mathrm{NO}_{2}$ was measured in the final 4 weeks of the study rather than over the entire study period, it was necessary to restrict the analysis of indoor $\mathrm{NO}_{2}$ adjusted for outdoor $\mathrm{NO}_{2}$ to the final 4 weeks of the study. When this restriction was applied to the results in table 4 , the sample size was greatly reduced and, thus, there was a reduction in power; this is seen in the reduction in number of child days (e.g. 22,516 to 5,257, for evening FEV1). However, the adjustment for outdoor $\mathrm{NO}_{2}$ did not significantly reduce the effect size of indoor $\mathrm{NO}_{2}$ on symptoms or lung function, indicating that the effect of indoor $\mathrm{NO}_{2}$ on lung function was independent of the effect of outdoor $\mathrm{NO}_{2}$. Similarly, the effect of outdoor $\mathrm{NO}_{2}$ was independent of the effect of indoor $\mathrm{NO}_{2}$ (data not shown).

The results presented in tables 3-6 were also adjusted for a range of confounders (age, sex, smoking, the outcome at baseline, parental history of asthma, region, ethnicity, the effect of the intervention and low income). These adjustments made no substantial change to the results. However, when the models were adjusted for temperature, while most results were unchanged, the significant association between indoor $\mathrm{NO}_{2}$ and wheezing disappeared and the association between indoor $\mathrm{NO}_{2}$ and preventer use became significant.

TABLE 4 Effect per logged unit increase of indoor nitrogen dioxide $\left(\mathrm{NO}_{2}\right)$ on daily lung function measures in children during the winter of 2006

\begin{tabular}{|c|c|c|c|c|}
\hline Lung function measurement & Child days $n$ & Subjects n & Effect size & $95 \% \mathrm{Cl}$ \\
\hline Evening FEV 1 mL & 22516 & 346 & -13.21 & $-26.03--0.38$ \\
\hline Morning FEV $1 \mathrm{~mL}$ & 21335 & 337 & -17.25 & $-27.63--6.88$ \\
\hline Evening PEFR L·min ${ }^{-1}$ & 22518 & 346 & -0.97 & $-2.29-0.36$ \\
\hline Morning PEFR L· $\min ^{-1}$ & 21619 & 338 & -1.33 & $-2.69-0.02$ \\
\hline
\end{tabular}

FEV1: forced expiratory volume in $1 \mathrm{~s}$; PEFR: peak expiratory flow rate. 


\begin{tabular}{|c|c|c|c|c|}
\hline $\begin{array}{ll}\text { TABLE } 5 & \begin{array}{l}\text { Effect per loc } \\
\text { over } 4 \text { weeks }\end{array}\end{array}$ & $\begin{array}{l}\text { ncrease of ou } \\
\text { nber } 2006^{\#}\end{array}$ & itrogen dio> & on daily asthma symptom sc & dication use \\
\hline Health event & Child days $n$ & Subjects $n$ & $\begin{array}{l}\text { Change in mean symptom rate } \\
\text { per unit increase in } \mathrm{NO}_{2}\end{array}$ & $95 \% \mathrm{Cl}$ \\
\hline Cough at night & 6104 & 294 & 1.07 & $0.79-1.45$ \\
\hline Cough during the day & 6433 & 299 & 0.95 & $0.73-1.24$ \\
\hline Wheeze at night & 6072 & 293 & 1.23 & $0.82-1.85$ \\
\hline Wheeze during the day & 6413 & 298 & 1.18 & $0.83-1.68$ \\
\hline Wheeze on waking & 6082 & 292 & 1.12 & $0.76-1.65$ \\
\hline Preventer use & 6530 & 299 & 1.47 & $0.96-2.26$ \\
\hline Reliever puffs per day & 6443 & 298 & 1.46 & $0.94-2.27$ \\
\hline Lower respiratory symptoms & 6359 & 296 & 1.09 & $0.78-1.51$ \\
\hline
\end{tabular}

\section{DISCUSSION}

The $\mathrm{NO}_{2}$ levels reported in this study are higher than those previously reported indoors in the UK (Ashford), Spain (Menorca) and Sweden (Uppsala) [25, 26], and are comparable to those previously measured in New Zealand (Nelson), Italy (Po River Delta) and the USA $[3,27,28]$. However, $\mathrm{NO}_{2}$ levels in our study were lower than those reported in Barcelona (Spain) [25]. The WHO annual average outdoor $\mathrm{NO}_{2}$ guideline of $40 \mu \mathrm{g} \cdot \mathrm{m}^{-3}$ [29] was exceeded during the 2006 winter period in $13.8 \%$ of homes and $1.9 \%$ of the outdoor samples.

Our findings that indoor $\mathrm{NO}_{2}$ was associated with greater daily reports of lower and upper respiratory tract symptoms, more frequent coughing and wheezing and a reduction in morning and evening FEV1 are consistent with previous findings from observational studies $[1,12,20,28,30]$. The conclusion of one systematic review stated that average hourly $\mathrm{NO}_{2}$ values of $80 \mathrm{ppb}\left(\sim 154 \mu \mathrm{g} \cdot \mathrm{m}^{-3}\right)$ are likely to cause respiratory symptoms in the general population of children [20]. Furthermore, a study by JARVIS et al. [31] reported a $3.1 \%$ reduction in the lung function (FEV1 \% predicted) of females who used gas stoves in comparison to females who used other forms of cooking. In a later publication by JARVIS et al. [32], it was noted that burning gas appliances indoors may produce more of an effect on respiratory health than is reflected by $\mathrm{NO}_{2}$ levels due to the failure to account for the adverse effects of nitrous acid, which is generated directly from gas combustion and indirectly from $\mathrm{NO}_{2}$.

Increasing levels of outdoor $\mathrm{NO}_{2}$ were not significantly associated with an increase in respiratory symptoms or a reduction in lung function. The relatively large estimated effect for reduced lung function may be an accidental finding due to the smaller sample size for outdoor $\mathrm{NO}_{2}$ measurement or it may be a consequence of the respiratory effects of other combustion products and fine particulates associated with outdoor sources of $\mathrm{NO}_{2}$ [33]. The effect estimates of both indoor and outdoor $\mathrm{NO}_{2}$ changed little when mutually adjusted, indicating that these factors may be independent. This suggests that indoor $\mathrm{NO}_{2}$ mainly reflects differing sources and/or mechanisms for reducing lung function than outdoor $\mathrm{NO}_{2}$.

The pathophysiological effect of $\mathrm{NO}_{2}$ on the respiratory system may include early alterations in airway calibre and/or viscoelastic properties of the peripheral lung and delayed or impaired gas exchange and pulmonary function abnormalities [34]. Children are particularly vulnerable to the effects of air pollution as they breathe $50 \%$ more air per $\mathrm{kg}$ of body weight than adults [35]. Our findings are based on a post hoc secondary analysis of a study designed to investigate the effects of a heating intervention. We acknowledge the shortcomings of this design for investigating the study hypothesis, but are also aware that due to having two groups with different heating

TABLE 6 Effect per logged unit increase of outdoor nitrogen dioxide $\left(\mathrm{NO}_{2}\right)$ on daily lung function measures in children over 4 weeks in September $2006^{\#}$

\begin{tabular}{|c|c|c|c|c|}
\hline Lung function measurement & Child days $n$ & Subjects n & Effect size & $95 \% \mathrm{Cl}$ \\
\hline Evening FEV1 mL & 5257 & 286 & -87.91 & $-191.02-15.23$ \\
\hline Morning FEV 1 mL & 4858 & 279 & -76.17 & $-168.70-16.36$ \\
\hline Evening PEFR L·min ${ }^{-1}$ & 5257 & 286 & -10.17 & $-21.33-0.98$ \\
\hline Morning PEFR L. $\min ^{-1}$ & 5007 & 280 & -9.60 & $-20.71-1.51$ \\
\hline
\end{tabular}

FEV1: forced expiratory volume in $1 \mathrm{~s}$; PEFR: peak expiratory flow rate. ${ }^{\#}$ : during the period when outdoor $\mathrm{NO}_{2}$ was measured 
systems, we are guaranteed a large spread of indoor $\mathrm{NO}_{2}$, and increased power. Furthermore, while the heating intervention itself was not quite significant in improving lung function $(\mathrm{p}=0.051)$ [22], the overall negative effect of indoor $\mathrm{NO}_{2}$ on lung function suggests that the intervention may have been effective in those houses where there was a marked reduction in $\mathrm{NO}_{2}$.

A further limitation of our study is that while we took daily health measures, the $\mathrm{NO}_{2}$ levels were measured as 4-week averages. Therefore, in the analysis the daily outcome from the first day of a sampling period is associated with a 4-week average that includes future $\mathrm{NO}_{2}$ levels. Another limitation of this study is that short-term peak levels of exposure were not measured. Repeated exposures to short-term peaks of $\mathrm{NO}_{2}$ have been suggested to be a more important determinant of airway symptoms than total dose or absolute background exposure levels [36-38]. PiLOtTo et al. [39] reported that exposure to hourly peak levels of $\sim 80 \mathrm{ppb}$ in comparison to background levels of $20 \mathrm{ppb}$ were associated with an increase in sore throats, colds and absences from school in children aged 6-11 yrs. However, as the design of our study was a household intervention trial involving 409 homes, measuring $\mathrm{NO}_{2}$ peak levels was not practical.

Another limitation of this study was that ventilation rates were not measured. However, in the New Zealand population, people tend to ventilate a dwelling at levels higher than the natural ventilation rates of an unoccupied, fully closedup building [40]. Furthermore, as New Zealand homes are generally built out of timber frames with single glazing, they tend to be draughty.

The final limitation of this study was that participants were not blinded to the replacement of their heater, which could have affected the reporting of symptoms and led to an overestimation of the effect of reduced $\mathrm{NO}_{2}$ exposure. However, outcome measures also included objective (PEFR and FEV1) measures and these also declined with increasing $\mathrm{NO}_{2}$. Moreover, after randomisation, children in both groups had similar characteristics, including previous use of gas heaters, parental history of asthma, smoking indoors and sex, thus, confounding by indoor factors is unlikely to explain the findings. We did not collect information on potential outdoor confounders or effect modifiers, such as traffic volume, which may explain the influence of outdoor $\mathrm{NO}_{2}$ on lung function measurements.

Indoor $\mathrm{NO}_{2}$ was significantly associated with an increase in asthma symptoms and reduced lung function (FEV1), while outdoor $\mathrm{NO}_{2}$ was not significantly associated with reduced lung function (FEV1 and PEFR) or asthma symptoms. These findings indicate that reducing $\mathrm{NO}_{2}$ exposure indoors is important in improving the respiratory health of children with asthma.

\section{SUPPORT STATEMENT}

The Housing, Heating and Health Study Team greatly appreciates the funding support from: the Health Research Council of New Zealand; Contact Energy; Ministry for the Environment; Housing New Zealand Corporation; Hutt Valley District Health Board; Capital and Coast District Health Board; and the LPG Association. A full list of public sponsors is available at www.wnmeds.ac.nz/healthyhousing.html

\section{CLINICAL TRIAL}

This study is registered at ClinicalTrials.gov with the identifier NCT00489762.

\section{STATEMENT OF INTEREST}

A statement of interest for P. Howden-Chapman can be found at www. erj.ersjournals.com/site/misc/statements.xhtml

\section{ACKNOWLEDGEMENTS}

In addition to the authors the Housing, Heating and Health Study Research Team consists of: D. Shields, H. Viggers and S. Free (Housing and Health Research programme, University of Otago, Wellington South, New Zealand); R. Phipps, P. Fjallstrom and M. Boulic (School of Engineering and Advanced Technology, Massey University, Palmerston North, New Zealand); M. Cunningham (BRANZ, Porirua, New Zealand); B. Lloyd (Energy Studies, University of Otago, Dunedin, New Zealand); C. Cunningham (Research Centre for Mäori Health and Development, Massey University, Wellington, New Zealand); R. Chapman (School of Geography, Environment and Earth Sciences, Victoria University, Wellington); C. Bullen and A. Woodward (School of Population Health, University of Auckland, Auckland, New Zealand). We are grateful to the outstanding efforts of the community coordinators involved in this study and we thank all the families and children who have given their time to be part of this trial.

\section{REFERENCES}

1 Belanger K, Gent JF, Triche EW, et al. Association of indoor nitrogen dioxide exposure with respiratory symptoms in children with asthma. Am J Respir Crit Care Med 2006; 173: 297-303.

2 Pilotto LS, Nitschke M, Smith BJ, et al. Randomized controlled trial of unflued gas heater replacement on respiratory health of asthmatic children. Int J Epidemiol 2004; 33: 208-214.

3 Simoni M, Carrozzi L, Baldacci S, et al. The Po River Delta (North Italy) indoor epidemiological study: effects of pollutant exposure on acute respiratory symptoms and respiratory function in adults. Arch Environ Health 2002; 57: 130-136.

4 Shima M, Adachi M. Effect of outdoor and indoor nitrogen dioxide on respiratory symptoms in schoolchildren. Int J Epidemiol 2000; 29: 862-870.

5 World Health Organization. Air Quality Guidelines: Global Update 2005. Particulate matter, ozone, nitrogen dioxide and sulfur dioxide. Geneva, World Health Organization, 2005. www. euro.who.int/_data/assets/pdf_file/0005/78638/E90038.pdf.

6 Folinsbee LJ. Does nitrogen dioxide exposure increase airways responsiveness? Toxicol Ind Health 1992; 82: 273-283.

7 Bauer MA, Utell MJ, Morrow PE, et al. Inhalation of $0.30 \mathrm{ppm}$ nitrogen dioxide potentiates exercise-induced bronchospasm in asthmatics. Am Rev Respir Dis 1986; 134: 1203-1208.

8 Pilotto LS, Douglas RM. Nitrogen dioxide, gas heating and respiratory illness. Aust J Public Health 1992; 167: 295-296.

9 Samet JM, Utell MJ. The risk of nitrogen dioxide: what have we learned from epidemiological studies? Toxicol Ind Health 1990; 6: 247-262.

10 Ponsonby AL, Glasgoe N, Gatenby P, et al. The relationship between low level nitrogen dioixde exposure and child lung function after cold air challenge. Clin Exp Allergy 2001; 31: 1205-1212.

11 Garrett MH, Hooper MA, Hooper BM, et al. Respiratory symptoms in children and indoor exposure to nitrogen dioxide and gas stoves. Am J Respir Crit Care Med 1998; 158: 891-895.

12 Chauhan AJ, Inskip HM, Linaker $\mathrm{CH}$, et al. Personal exposure to nitrogen dioxide $\left(\mathrm{NO}_{2}\right)$ and the severity of virus-induced asthma in children. Lancet 2003; 361: 1939-1944.

13 Linaker $\mathrm{CH}, \mathrm{Coggon} \mathrm{D}, \mathrm{Holgate} \mathrm{ST}$, et al. Personal exposure to nitrogen dioxide and risk of airflow obstruction in asthmatic children with upper respiratory infection. Thorax 2000; 55: 930-933. 
14 Belanger K, Beckett W, Triche E, et al. Symptoms of wheeze and persistent cough in the first year of life: associations with indoor allergens, air contaminants and maternal history of asthma. Am J Epidemiol 2003; 158: 195-202.

15 Samet JM, Lambert WE, Skipper BJ, et al. Nitrogen dioxide and respiratory illness in children. Part I: Health outcomes. Res Rep Health Eff Inst 1993; 58: 1-32.

16 Cesaroni G, Badaloni C, Porta D, et al. Comparison between various indices of exposure to traffic-related air pollution and their impact on respiratory health in adults. Occup Environ Med 2008; 65: 683-690.

17 Arbex MA, Martins LC, Pereira LA, et al. Indoor $\mathrm{NO}_{2}$ air pollution and lung function of professional cooks. Braz J Med Biol Res 2007; 40: 527-534.

18 Kwon HJ, Lee SG, Jee YK, et al. [Effects of personal exposure to nitrogen dioxide on peak expiratory flow in asthmatic patients.]. J Prev Med Public Health 2007; 40: 59-63.

19 Salome CM, Brown NJ, Marks GB, et al. Effect of nitrogen dioxide and other combustion products on asthmatic subjects in a homelike environment. Eur Respir J 1996; 9: 910-918.

20 Nictschke M, Smith BJ, Pilotto LS, et al. Respiratory health effects of nitrogen dioxide exposure and current guidelines. Int J Environ Health Res 1999; 9: 39-53.

21 Latza U, Gerdes S, Baur X. Effects of nitrogen dioxide on human health: systematic review of experimental and epidemiological studies conducted between 2002 and 2006. Int J Hyg Environ Health 2009; 212: 271-287.

22 Howden-Chapman P, Pierse N, Nicholls S, et al. Effects of improved home heating on asthma in community dwelling children: randomised controlled trial. BMJ 2008; 337: a1411.

23 Gillespie-Bennett J, Pierse N, Wickens K, et al. Sources of nitrogen dioxide $\left(\mathrm{NO}_{2}\right)$ in New Zealand homes: findings from a community randomized controlled trial of heater substitutions. Indoor Air 2008; 18: 521-528.

24 Palmes ED, Gunnison AF, DiMattio J, et al. Personal sampler for nitrogen dioxide. Am Ind Hyg Assoc J 1976; 37: 570-577.

25 Garcia-Algar O, Pichini S, Basagaña X, et al. Concentrations and determinants of $\mathrm{NO}_{2}$ in homes of Ashford, UK and Barcelona and Menorca, Spain. Indoor Air 2004; 14: 298-304.

26 Sakai K, Norbäck D, Mi Y, et al. A comparison of indoor and outdoor air pollutants in Japan and Sweden: formaldehyde, nitrogen dioxide and chlorinated volatile organic compounds. Environ Res 2004; 94: 75-85.
27 Kingham S, Petrovic N. Nitrogen dioxide in Nelson homes, New Zealand. Clean Air Environ Qual J 2005; 39: 5.

28 Neas LM, Dockery DW, Ware JH, et al. Association of indoor nitrogen dioxide with respiratory symptoms and pulmonary function in children. Am J Epidemiol 1991; 134: 204-219.

29 World Health Organization. Air Quality Guidelines for Europe. WHO Regional Publications European Series. Copenhagen, WHO Regional Office for Europe, 1987.

30 Tunnicliffe WS, Burge PS, Ayres JG. Effect of domestic concentrations of nitrogen dioxide on airway responses to inhaled allergen in asthmatic patients. Lancet 1994; 344: 1733-1736.

31 Jarvis D, Chinn S, Luczynska C, et al. Association of respiratory symptoms and lung function on young adults with use of domestic gas appliances. Lancet 1996; 347: 426-31.

32 Jarvis DL, Leaderer BP, Chinn S, et al. Indoor nitrous acid and respiratory symptoms and lung function in adults. Thorax 2005; 60: $474-479$.

33 Brunekreef B, Holgate ST. Air pollution and health. Lancet 2002; 360: $1233-1242$

34 Januszkiewicz AJ, Snapper JR, Sturgis JW, et al. Pathophysiological responses of sheep to brief high-level nitrogen dioxide exposure. Inhal Toxicol 1992; 4: 359-372.

35 Bateson TF, Schwartz J. Children's response to air pollutants. J Toxicol Environ Health A 2008; 71: 238-243.

36 Franklin $\mathrm{P}$, Runnion T, Farrar D, et al. Comparison of peak and average nitrogen dioxide concentrations inside homes. Atmos Environ 2006; 40: 7449-7454.

37 Gardner DE, Miller FJ, Blommer EJ, et al. Influence of exposure mode on the toxicity of nitrogen dioxide. Environ Health Perspect 1979; 30: 23-29.

38 Graham JA, Gardner DE, Blommer EJ, et al. Influence of exposure patterns of nitrogen dioxide and modifications by ozone on susceptibility to bacterial infectious disease in mice. J Toxicol Environ Health 1987; 21: 113-125.

39 Pilotto LS, Douglas RM, Samet JM. Respiratory effects associated with indoor nitrogen dioxide exposure in children. Int J Epidemiol 1997; 26: 788-795.

40 Crane J, Ellis I, Siebers R, et al. A pilot study of the effect of mechanical ventilation and heat exchange on house-dust mites and Der p 1 in New Zealand. Allergy 1998; 53: 755-762. 